\title{
UJI AKTIVITAS ANTIOKSIDAN DARI EKSTRAK TOTAL ALGA HIJAU Halimeda opuntia Linnaeus DAN Halimeda macroloba Decaisne DARI PERAIRAN TELUK TOTOK
}

\author{
(Antioxidant Activity Test of Total Extract of Halimeda opuntia Linnaeus and Halimeda \\ macroloba Decaisne from Totok Bay Waters)
}

\author{
Regina Leibo ${ }^{1 *}$, Desy M. H. Mantiri ${ }^{1}$, Grevo S, Gerung ${ }^{1}$
}

1. Program Studi IImu Kelautan, Fakultas Perikanan dan IImu Kelautan, Universitas Sam Ratulangi, Manado'

*e-mail : reginaleibo06@gmail.com

The study was conducted to analyze the antioxidant activity of Halimeda opuntia Linnaeus and Halimeda macroloba Decaisne. The samples were collected from Totok Bay waters, Ratatotok, Southeast Minahasa Regency and continued with laboratory analysis. The antioxidant activity test applied a spectrophotometer and 1,1-phenyl-2-picryhydrazyl (DPPH). The results showed that total pigmen extract of Halimeda opuntia and Halimeda macroloba that lived in relatively polluted areas could still grow and contained antioxidants. The inhibition rate of both extracts was also generally very high. The smaller the absorbance value is, the higher the inhibition value and the antioxidant activity will be.

\begin{abstract}
Keywords : Antioxidant, Halimeda opuntia, Halimeda macroloba
Penelitian ini dilakukan dengan tujuan untuk menganalisis aktivitas antioksidan dari Halimeda opuntia Linnaeus dan Halimeda macroloba Decaisne. Sampel diperoleh dari perairan Teluk Totok, Ratatotok, Kabupaten Minahasa Tenggara dan dilanjutkan dengan analisis laboratorium. Analisis uji aktivitas antioksidan dengan alat Spektrofotometer dan menggunakan metode 1,1-phenil2-pikrihidrazil (DPPH). Hasil penelitian memperlihatkan bahwa ekstrak pigmen total Halimeda opuntia dan Halimeda macroloba yang hidup di daerah relatif tercemar masih tetap berkembang dan memiliki kandungan antioksidan. Sesuai dengan presentase nilai inhibisi dari kedua ekstrak umumnya sangat tinggi. Karena semakin kecil nilai absorban maka semakin tinggi nilai inhibisi dimana aktivitas antioksidan pada ekstrak semakin tinggi.
\end{abstract}

Kata kunci : Antioksidan, Halimeda opuntia, Halimeda macroloba

\section{PENDAHULUAN}

Di perairan terdapat bermacammacam makluk hidup baik berupa tumbuhan air maupun hewan. Salah satu yang tumbuh dan berkembang di laut adalah alga. Alga adalah sekelompok organisme autotrof yang tidak memiliki organ seperti yang dimiliki tumbuhan (akar, batang, daun, dsb). Alga merupakan kelompok organisme yang bervariasi, baik bentuk, ukuran, maupun komposisi senyawa kimia lainnya (Kawaroe, 2010).

Secara tradisional alga makro telah lama digunakan sebagai bahan makanan dan obat-obatan, karena kaya akan mineral, elemen makro dan elemen mikro lainnya. Beberapa jenis alga yang mengandung mineral penting yang berguna untuk metabolisme tubuh seperti lodin, calsium dan selenium

(Burtin, 2006).

Antioksidan merupakan senyawa yang dapat menetralkan atau meredam radikal bebas, serta menghambat terjadinya oksidasi pada sel tubuh, sehingga dapat mencegah atau mengurangi terjadinya kerusakan sel (Abdul, 2003). Radikal bebas merupakan atom atau molekul yang memiliki satu atau lebih elektron yang tidak berpasangan yang dapat menarik elektron dari senyawa lain sehingga terbentuk radikal bebas 
antara lain dapat merusak molekul makro pembentuk sel yaitu : protein, karbohidrat lemak dan deoxyribo nuleic acid (DNA) (Anon., 2004). Akibatnya sel menjadi rusak dan menyebabkan berbagai jenis penyakit seperti kanker, anemia, asma, inflamasi, degerenasi syaraf, parkinson, dan proses penuaan dini (Polterait, 1997) oleh kerana itu antioksidan sangat bermanfaat bagi kesehatan dan berperan penting untuk mempertahankan mutu produk pangan.

Berdasarkan hal tersebut, maka penelitian ini dilakukan dengan tujuan untuk menganalisis aktivitas antioksidan yang terdapat pada alga makro spesies Halimeda opuntia dan Halimeda macroloba dari perairan yang relatif tercemar oleh logam berat.

\section{METODE PENELITIAN}

Lokasi penelitian berada pada perairan Teluk Totok, Kabupaten Minahasa Tenggara, Sulawesi Utara dan Laboratorium Biomolekuler dan Farmasitika Laut, Fakultas Perikanan dan IImu Kelautan, Universitas Sam Ratulangi. Kegiatan penelitan diawali dengan penyiapan alat dan bahan yang digunakan dalam menunjang penelitian ini. Kemudian pengambilan sampel dilakukan dengan cara mencabut secara perlahan sampel alga dengan tangan langsung dari substratnya saat surut terendah. Sampel alga setelah diambil dari lokasi, selanjutnya dicuci dengan air laut dan dimasukan ke dalam kantong plastik serta diletakkan dalam kotak pendingin (coolbox). Selanjutnya sampel dibawa ke laboratorium untuk diidentifikasi dan dianalsis aktivitas antioksidan.

\section{Uji Aktivitas Antioksidan}

Sebelum dilakukan uji kandungan aktivitas antioksidan pada sampel $H$. opuntia dan $H$. macroloba dengan alat spektrofotometer, hal yang perlu dilakukan adalah melakukan pengenceran pada larutan. Langkahlangkah yang dilakukan adalah sebagai berikut (Miryanti et al 2011). Parameter yang digunakan untuk menghitung aktivitas $I C_{50}$. Semakin kecil konsentrasi $\mathrm{IC}_{50}$, maka semakin besar aktivitas antioksidannya. Aktivitas antioksidan dari kedua ekstrak sampel alga tersebut menggunakan metode DPPH (1,1-difenil2-dipikrihidrazil). Metode DPPH dipilih karena sederhana, mudah, cepat, pekat, serta hanya memerlukan sedikit sampel (Hanani et al., 2005).

\section{Cara Kerja}

Menyiapkan alat dan bahan yang akan digunakan untuk penelitian, melarutkan serbuk DPPH dengan konsentrasi 100 ppm dengan menggunakan rumus $\mathrm{V}_{1} \mathrm{M}_{1}=\mathrm{V}_{2} \mathrm{M}_{2}$. Larutan tersebut akan menjadi warna ungu pekat. Sebelum melakukan pengenceran untuk larutan yang lain, maka alfa tokoferol yang dalam bentuk kapsul gel digunakan cairan di dalam kapsul sebanyak $0.1 \mathrm{ml}$. Kemudian melakukan terhadap ekstrak sampel dalam pigmen total. Masing-masing sampel diambil $1.1 \mathrm{ml}$ untuk dilarutkan dengan metanol pada konsentrasi 100.000 ppm diaduk hingga homogen. Dan diencerkan lagi pada konsentrasi 1000 ppm dan 100 ppm. Kemudian pengenceran terhadap alfa tokoferol, dalam hal ini sebagai pembanding untuk uji antioksidan pada alga. Alfa tokoferol diencerkan pada konsentrasi 100 ppm dan 10 ppm. Kemudian melakukan pengenceran terhadap DPPH, serbuk DPPH dilarutkan pada konsentrasi 100 ppm, 75 ppm, 50 ppm dan 25 ppm. Kemudian ukur nilai absorban dengan mengunakan spektrofotometer pada serapan $\lambda 515(\mathrm{~nm})$. 


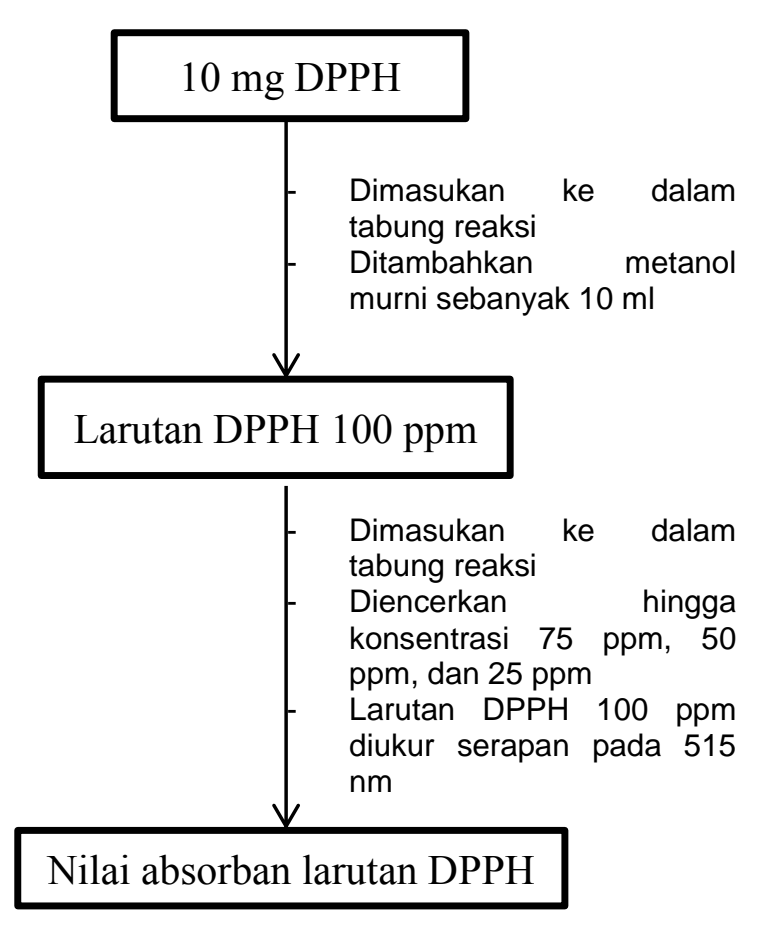

Gambar 1. Bagan Alir nilai absorban larutan DPPH

\section{HASIL DAN PEMBAHASAN}

\section{Hasil Identifikasi}

Hasil identifikasi sampel alga hijau spesies H.opuntia dan $H$. macroloba yang didapati dari perairan Teluk Totok. Buku identifikasi yang digunakan adalah Kepel dan Baulu (2013). Identifikasi sampel dengan cara melihat morfologi sampel alga hijau kemudian membandingkannya dengan buku identifikasi. Adapun ciri-ciri morfologi spesies $H$. macroloba yang diamati yaitu memiliki percabangan ratarata 3-4 percabangan. Memiliki thallus yang dominan berwarna hijau yang disebabkan oleh klorofil a dan b sehingga warna pigmen-pigmen lain seperti karatenoid dan xantofil tidak terlihat, bersegmen agak tebal, dan bercabang. Selain itu alga ini jenis hidup di perairan substrat pasir berbatu dan memiliki karbon organik dan zat yang dapat dimanfaatkan sebagai bahan obatobatan.

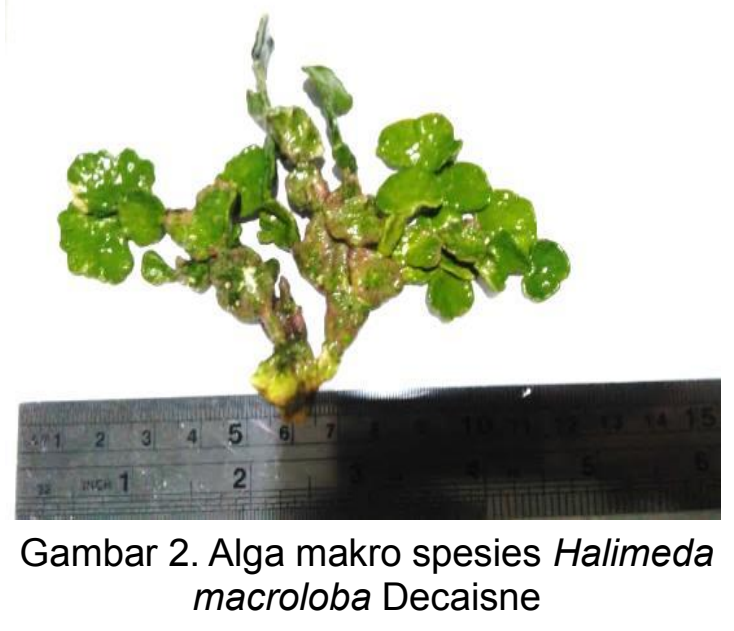

Hasil identifikasi sampel alga $H$. opuntia memiliki panjang $3-8 \mathrm{~mm}$, lebar 4-10 mm dan tebal 0,5-0,7 mm. Memiliki thallus yang membentuk rumpun berkelompok, mengandung kapur dan warnanya berubah menjadi putih ketika alga ini mati. Selain itu alga jenis ini hidup di perairan dengan substrat berpasir.

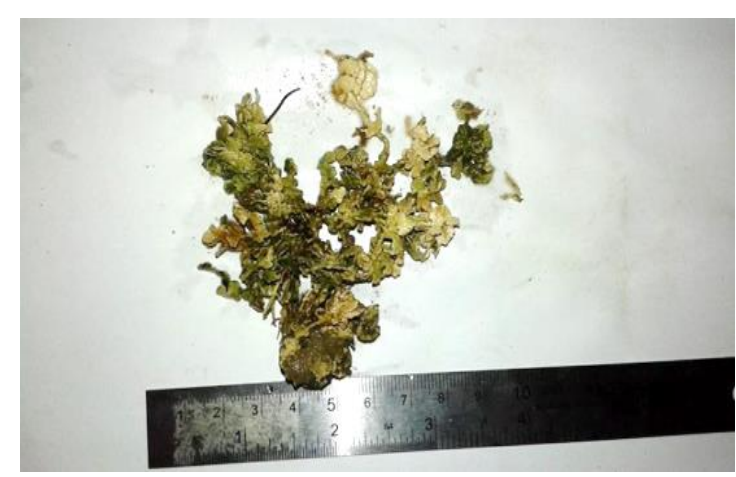

Gambar 3. Alga makro spesies Halimeda opuntia Linnaeus

\section{Hasil Pengujian Antioksidan}

Berdasarkan hasil ekstraksi yang telah dilakukan di Laboratorium Bimolekuler dan Farmasitika Kelautan, hasil ekstrak yang telah rendam dengan aseton ditimbang beratnya.

Tabel 1. Berat dan Karakteristik kedua makroalga .

\begin{tabular}{|l|l|l|}
\hline \multicolumn{1}{|c|}{ Sampel } & $\begin{array}{l}\text { Berat } \\
\text { awal }\end{array}$ & $\begin{array}{l}\text { Berat } \\
\text { ekstrak }\end{array}$ \\
\hline Halimeda macroloba & $245 \mathrm{~g}$ & $18,25 \mathrm{~g}$ \\
\hline Halimeda opuntia & $278 \mathrm{~g}$ & $23.21 \mathrm{~g}$ \\
\hline
\end{tabular}


Selanjutnya dilaksankan uji lanjut dengan menggunakan metode DPPH. Metode DPPH adalah suatu metode yang didasarkan pada kemampuan antioksidan untuk memperhambat radikal bebas dengan mendonorkan atom hydogen (Green, 2004).

Untuk mengetahui kandungan antioksidan pada ekstrak $H$. opuntia dan $H$. macroloba maka perlu direaksikan sampel larutan DPPH. Masing-masing ekstrak sampel dengan konsentrasi 1000 ppm direaksikan dengan larutan DPPH 75 ppm, 50 ppm, dan 25 ppm kemudian diukur nilai absorbannya pada spektrofotometer. Sama halnya juga dengan ekstrak yang berkonsentrasi 100 ppm.

Untuk zat pembanding yaitu Tokoferol (Vitamin E) menggunakan larutan yang sudah diencerkan menjadi 10 ppm untuk direaksikan dengan larutan DPPH yang berkonsentrasi 75 ppm, 50 ppm dan 25 ppm. Tokoferol merupakan antioksidan sintetik yang berfungsi sebagai antioksidan sekunder yaitu menangkap radikal bebas dan mencegah terjadinya reaksi berantai (Praptiwi et al 2006).

\section{Aktivitas antioksidan pada DPPH dan Kontrol}

DPPH dalam metanol murni, nilai absorbannya diukur pada serapan 515 $\mathrm{nm}$ tanpa ada penambahan bahan uji. Untuk kontrol tokoferol (Vitamin E) yang sudah diencerkan direaksikan dengan larutan DPPH untuk mengetahui aktivitas antioksidan. Dari hasil pengukuran nilai absorban DPPH yang diperoleh dapat ditentukan nilai penghambat radikal DPPH (\% inhibisi). DPPH yang merupakan radikal bebas akan memiliki nilai absorban yang tinggi. Nilai absorban pada larutan DPPH konsentrasi $75 \mathrm{ppm}$ yaitu 1,937, pada konsentrasi $50 \mathrm{ppm}$ nilai absorban 0,538 , dan pada $25 \mathrm{ppm}$ nilai absorban 0,139 . Nilai radikal bebas dapat dilihat pada Gambar 4.

Tokoferol (Vitamin E) merupakan antioksidan yang sudah dikomersilkan. kontrol ini direaksikan dengan larutan DPPH untuk mengetahui aktivitas antioksidan dengan mengukur nilai absorban pada spektrofotometer. Nilai absorban yang semakin rendah menandakan adanya aktivitas antioksidan. Persamaan linier pada kontrol adalah $y=0,2386 x+2,3144 \cdot R^{2}=$ 0,9777 .

Nilai $I^{50}$ merupakan bilangan yang menunjukan konsentrasi ekstrak (ppm) yang mampu menghambat proses oksidasi sebesar $50 \%$. Semakin kecil nilai $\mathrm{IC}^{50}$ maka semakin tinggi aktivitas antioksidan.

Nilai inhibisi dari larutan kontrol yang direaksikan dengan larutan DPPH dapat dilihat pada Gambar 5.

Aktivitas antioksidan yang kuat kontrol ada pada larutan $75 \mathrm{ppm}$. Semakin besar konsentrasi maka aktivitas antioksidan semakin kuat (Widyowati et.al. 2016)

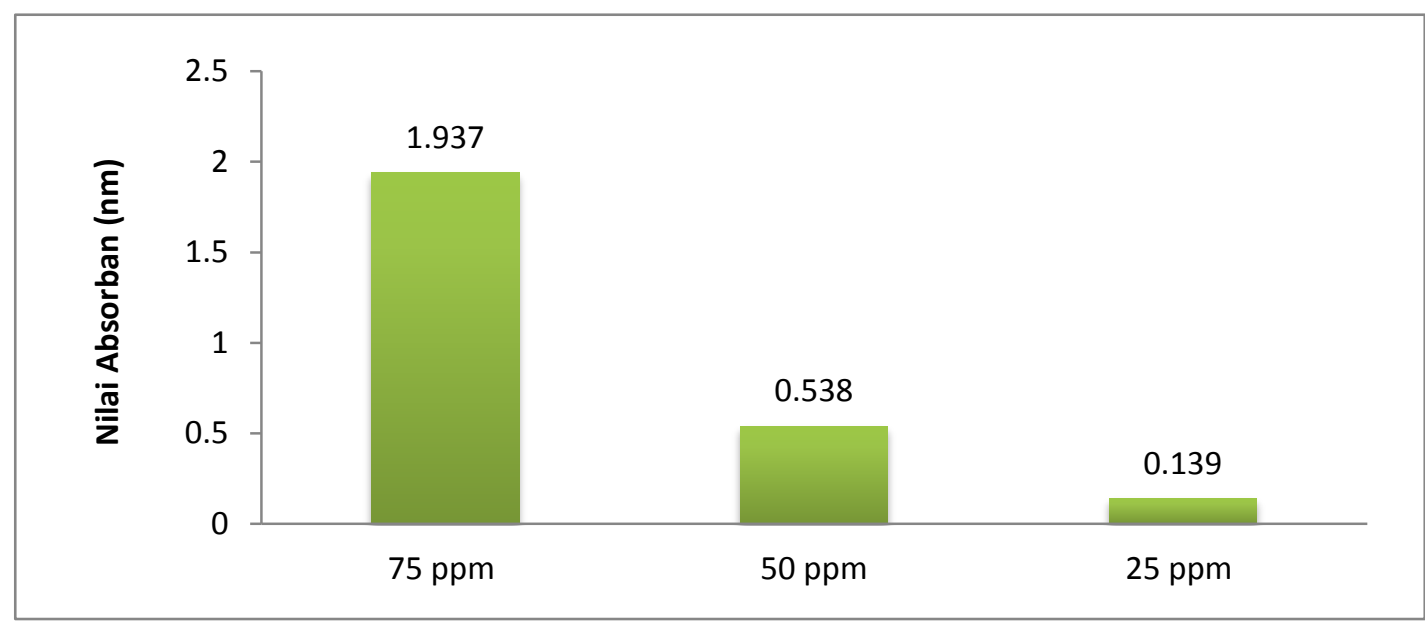

Gambar 4. Histogram nilai absorban 

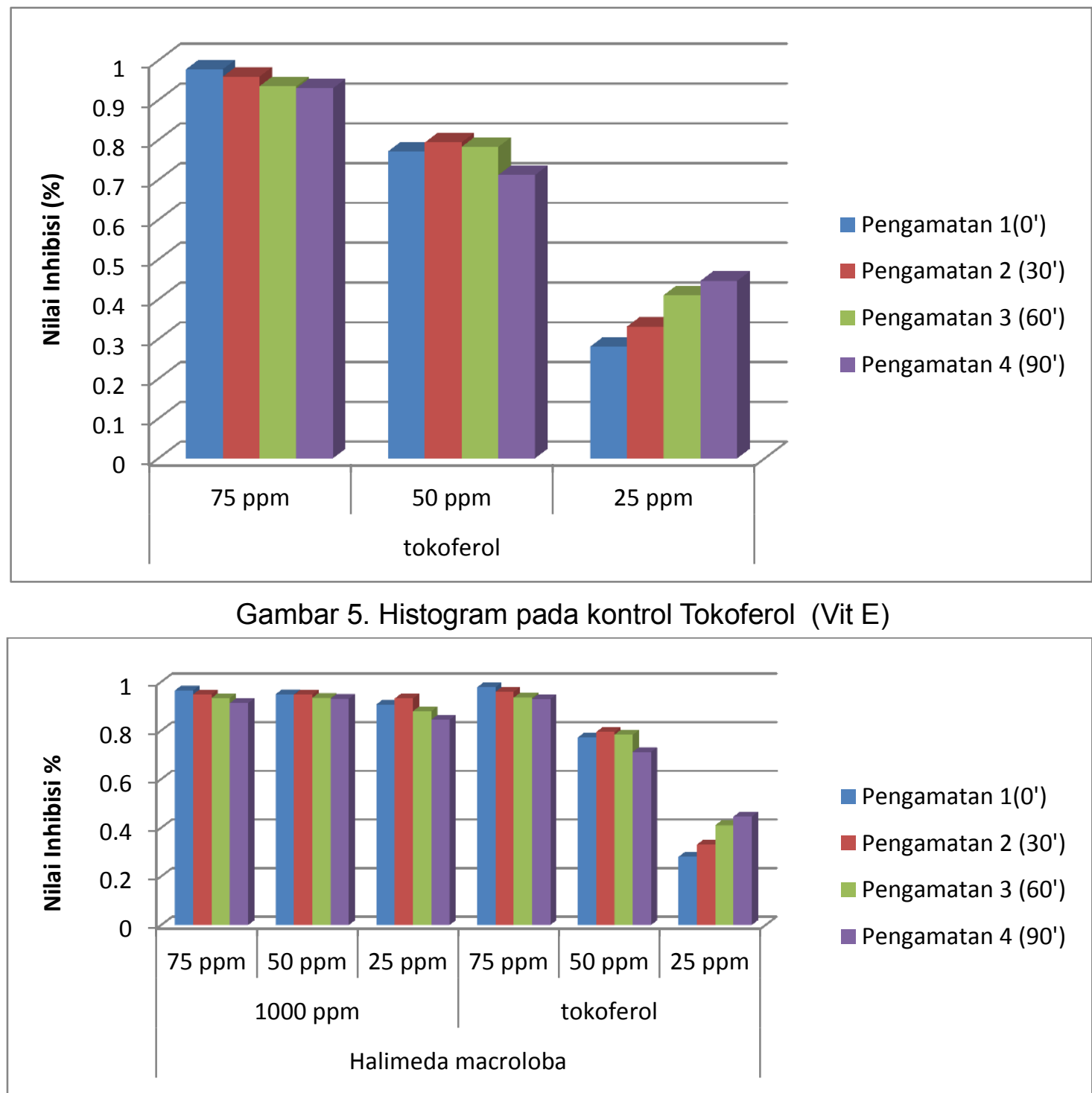

Gambar 6. Histogram nilai inhibisi ekstrak total Halimeda macroloba (1000 ppm) terhadap Kontrol.

\section{Aktivitas antioksidan pada ekstrak total Halimeda macroloba}

Pengujian yang dilakukan pada ekstrak total $H$. Macroloba menghasilkan ekstrak yang memiliki aktivitas antioksidan dengan adanya penurunan intensitas warna ungu pada DPPH. Pada ekstrak ini aktivitas antioksidan yang paling kuat ada pada ekstrak yang sudah direaksikan dengan larutan DPPH yang berkonsentrasi $75 \mathrm{ppm}$.

Dari grafik pada Gambar 6 dan 7 dapat diketahui bahwa ekstrak dari $H$. Macroloba memiliki aktivitas yang kuat karena ekstrak tersebut mendekati kontrol.

\section{Aktivitas Antioksidan pada Ekstrak Halimeda opuntia}

Pengujian yang dilakukan pada ekstrak total $H$. Opuntia menghasilkan ekstrak ini memiliki aktivitas antioksidan dengan adanya penurunan intensitas warna ungu pada DPPH. Aktivitas antioksidan yang kuat ada pada ekstrak yang direaksikan dengan larutan DPPH konsentrasi 75 ppm. Aktivitas antioksidan secara umum pada ekstrak konsentrasi 1000 ppm dan 100 ppm terhadp kontrol dapat dilihat pada Gambar 8. 


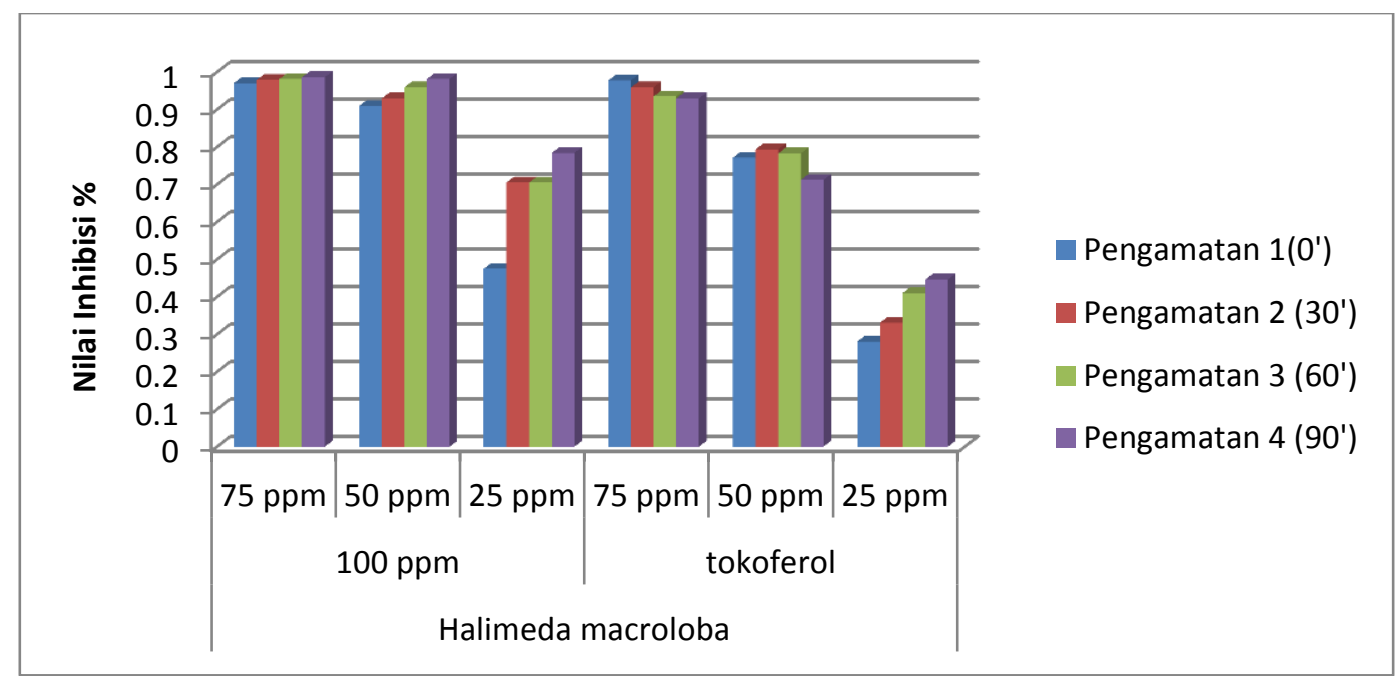

Gambar 7 . Histogram nilai inhibisi ekstrak total Halimeda macroloba (100 ppm) terhadap Kontrol.

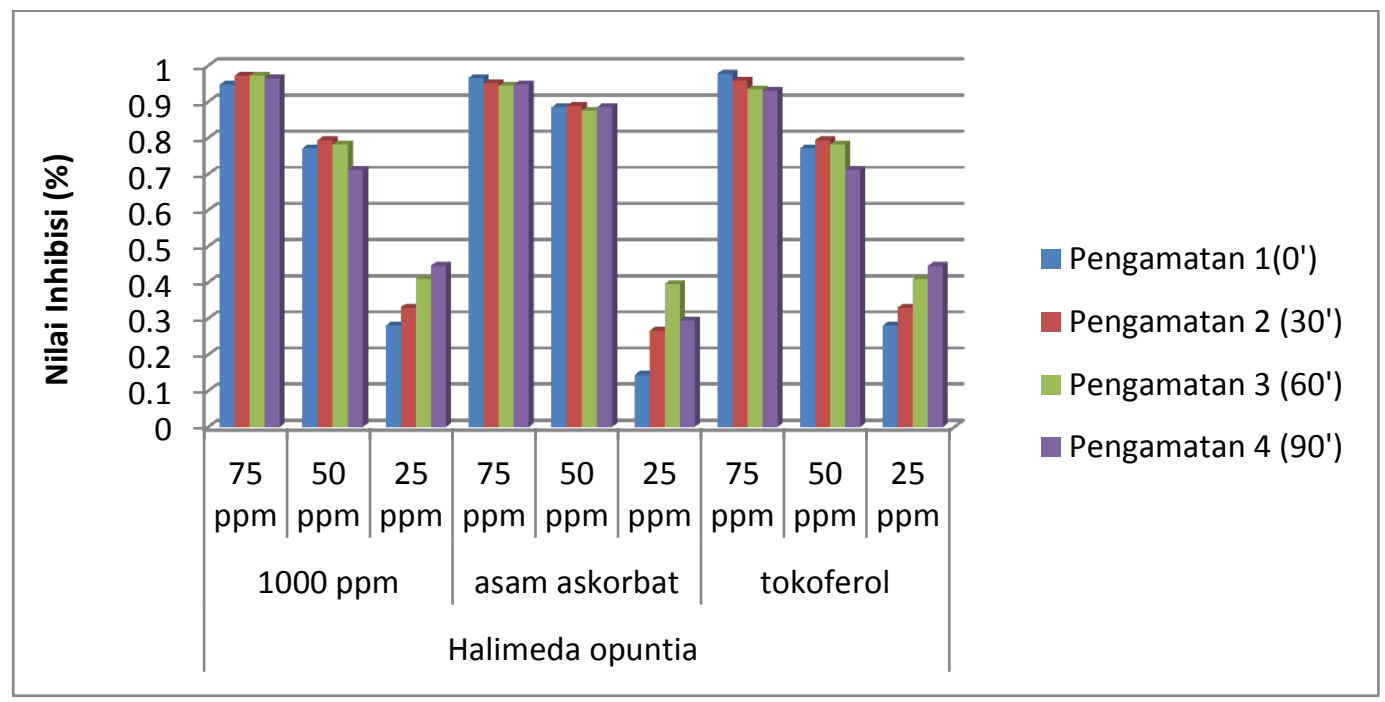

Gambar 8. Histogram nilai inhibisi ekstrak total Halimeda opuntia (100 ppm) terhadap Kontrol.

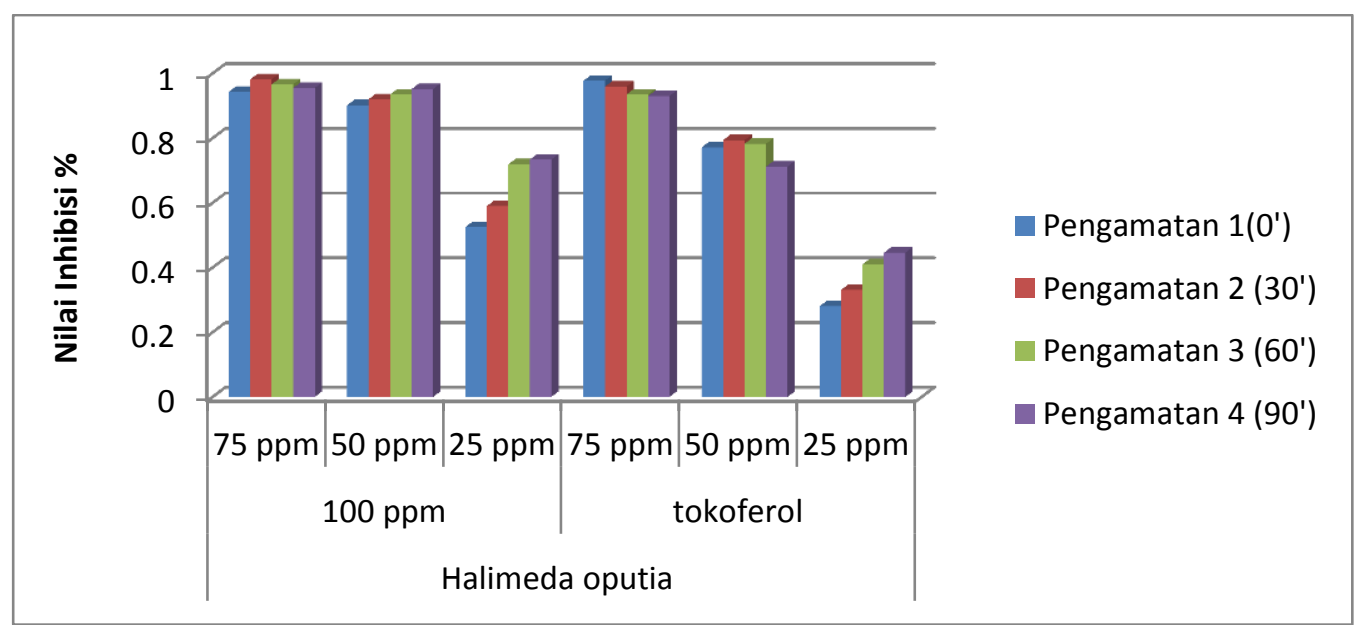

Gambar 9. Histogram nilai inhibisi ekstrak total Halimeda opuntia (1000 ppm) terhadap Kontrol. 
Dari semua pengujian yang telah dilakukan, rata - rata aktivitas antioksidan yang tinggi ada pada ekstrak yang telah direaksikan dengan larutan DPPH 75 ppm pada, karena pada konsentrasi ini donasi atom hidrogen dihasilkan dalam bentuk non radikal. Semakin besar konsentrasi ekstrak maka semakin besar perendamannya (Windono et. al 2004 dalam Rumengan dan Mantiri, 2015).

\section{KESIMPULAN}

Meskipun alga tersebut hidup didaerah yang relatif tercemar, alga tersebut dapat berkembang dan mempunyai kandungan aktivitas antioksidan yang sangat tinggi. Dari hasil pengujian kedua ekstrak sampel $H$. Macroloba dan $H$. Opuntia memiliki kandungan antioksidan. Karena presentase nilai inhibisi dari kedua ekstrak umumnya sangat tinggi karena semakin kecil nilai absorban maka semakin tinggi nilai inhibisi dimana aktivitas antioksidan pada ekstrak semakin tinggi.

\section{DAFTAR PUSTAKA}

Anonim. 2004. Antioksidan, radikal bebas dan penuaan. Http//www.kompas.com/komp as_cetak/03.05/11/fokus/306 $28 \overline{4} / \mathrm{htm}$.

Abdul., M. 2003. Peranan radikal bebas dan antioksidan dalam kesehatan dan penyakit. Http://ww.intisari.com/radikal. html.

Burtin, P. 2006. Nutritional value of seaweed. Electronic J. Environ. Agric . Food Chem 5 (3): 6.

Green, R. J. 2004. Antioxidant Activity of Peanut Plant
Tissues. (Thesis). Faculty of North Carolina State University. 82 pp.

Hanani, E , A. Uji Aktivitas antioksidan beberapa spons laut dari Kepulauan Seribu. Majalah ilmu kefarmasian. 11 (1): 11-15.

Kawaroe, M., Protono. T. 2010. Mikroalga Potensi dan Pemanfaatanya untuk Produksi Bio Bahan Bakar. IPB Press.

Kepel, R. C , Baulu S. 2013. Makroalga dan Lamun, keanekaragaman vegetasi laut di Maluku Tenggara, 86 Hal.

Miryanti, A., L. Sapei., K. Budiono S. Indra. 2011, Ekstraksi Antioksidan dari Kulit Buah Manggis (Gracinia mangostana L). Lembaga Penelitian dan Pengabdian Pada Masyarakat, Universitas Katolik Parahyangan.

Polteraid, O. 1997. Antioxidants and free radical scaven-gers of natural origin. Current Org. Chem 1. P. 415-440.

Rumengan, A.P ., D. M. H. Mantiri. 2015. Uji Aktivitas Antioksidan Ekstrak Alga Dictyosphaeria cavernova dari perairan teluk manado. Jurnal LPPM Bidang Sains dan Teknologi volume 2.

Widyowati. W. Sastiono. A. Rumampuk.R.J, 2008. Efek Toksikologi Logam. Penerbit ANDI. Yogyakarta. 